tion among the Dasuopu core, the Greenland cores, and the Antarctic cores. The Dasuopu values differ by an average of 66 ppbv from the Greenland values and 109 ppbv from the Antarctic values. The average difference between the Greenland and Antarctic records is 44 ppbv in the time interval of 0-1850 $A D$. The higher methane gradients between the Dasuopu core and the polar region suggest that the lowmiddle latitude acted as the most important methane source in the pre-industrial period.

\section{Conclusions}

We have produced a high-resolution record of atmospheric methane over the past 2,000 years from a sub-tropical and high-altitude ice core. The Dasuopu ice core record indicates an apparent trend of cli- matic warming and methane concentration increase over the past 2,000 years. An abrupt decrease in methane concentration appeared around 1800 AD., which is the coldest period of the Little Ice Age. After the cold period, methane concentrations again dramatically increased. The most important feature of the Dasuopu ice core record is that methane concentrations are higher than in the polar ice core records. This suggests that the low-middle latitudes act as an important methane source, at least during the last 2,000 years.

\section{References \\ Blunier T, Chappellaz, J., Schwander, J., et al. 1993: Atmospheric methane, record from a Greenland ice core over the last 1000 years. Geophys. Res. Lett., 20(20): 2219-2222. \\ Chappellaz, J., Barnola, J.M., Raynaud, D., Korotkev- ich, Y.S. and Lorius, C., 1990: Ice-core record of}

atmospheric methane over the past 160,000 years. Nature, 345: 127-131.

Etheridge, D. M, Steel, L. P., Francey, R. J. and Langenfelds, R. L., 1998: Atmospheric methane between 1000 A.D. and present: evidence of anthropogenic emissions and climatic variability. J. Geophy. Res., 103(D13): 15979-15995.

Thompson, L.G., Yao, T. and Mosley-Thompson, E., 2000: A High-resolution Millennial Record of the south Asian monsoon from Himalayan Ice Cores. Science, 289: 1916-1919.

Xu, B. and Yao, T., 1999: Enclosure of air in the firn at $7100 \mathrm{~m}$ altitude at Dasuopu glacier, J. Glaciology \& Geocryology, 21(4): 380-384.

Yao T., Duan, K., Xu, B. and Wang N., 2002: Temperature and methane changes over the past 1000 years recorded in Dasuopu ice core. Annals of Glaciology, 35: 379-383.

For full references please consult: www.pages-igbp.org/products/newsletters/ref2005_2.html

\title{
Recent Progress and Further Potential: High-resolution Holocene Climate Reconstruction with Coral Reefs in the South China Sea
}

\author{
Ke-Fu YU ${ }^{1}$ AND JiAN-XIN ZHA0 ${ }^{2}$ \\ 'South China Sea Institute of Oceanology, CAS, Guangzhou 510301, China; kyu@earth.uq.edu.au \\ ${ }^{2}$ Advanced Centre for Queensland University Isotope Research Excellence (ACQUIRE), University of Queensland QLD 4072, Australia; \\ j.zhao@uq.edu.au
}

Coral reefs, excellent archives for the environmental history of tropical oceans, are widely distributed in the South China Sea (SCS), which is the biggest enclosed marginal sea of the western Pacific, covering over $16^{\circ}$ in latitude and different climate conditions. The total area of the coral reefs in the SCS is about $7,300 \mathrm{~km}^{2}, \sim 2.5 \%$ of the world's coral reefs (Zhang et al., 2005). Recent research in the SCS focuses mainly on coral-based high-resolution climate reconstruction and coral reef ecological responses using geochemical and U-series geochronological tools, which reveal further potential for understanding of Holocene climate processes and events.

\section{High-resolution Geochemical Proxies for Sea Surface Temperatures (SST) and Salinity in the Mid-late Holocene \\ Combined monthly-resolution skel- etal $\delta^{18} \mathrm{O}, \delta^{13} \mathrm{C}, \mathrm{Sr} / \mathrm{Ca}$ and $\mathrm{Mg} / \mathrm{Ca}$ re- cords for corals from the SCS reveal annual cycles similar to instrumental SST.Theoretically, skeletal $\mathrm{Sr} / \mathrm{Ca}$ is a}

SST proxy, whereas skeletal $\delta^{18} \mathrm{O}$ is a function of both SST and salinity. Our results show that the Sr/Ca-SST relationship is a reliable thermometer, with calculated SST consistent with other independent evidence. By removing the SST-related component in the $\delta^{18} \mathrm{O}$ variation based on calculated $\mathrm{Sr} / \mathrm{Ca}$-SST values, one can obtain the residual $\delta^{18} \mathrm{O}$ that reflects the deviation of the past seawater $\delta^{18} \mathrm{O}$ from the modern value. Thus, the combination of coral $\mathrm{Sr} / \mathrm{Ca}$ and $\delta^{18} \mathrm{O}$ provides a powerful tool for past SST and salinity (related to evaporation and rainfall) reconstruction.

Unlike $\mathrm{Sr} / \mathrm{Ca}, \mathrm{Mg} / \mathrm{Ca}$ is not a reliable proxy for SST despite the fact that its annual cycles are wellcorrelated with instrumental SST. Using the empirical Mg/Ca-SST relationship, we obtained calculated $\mathrm{Mg} / \mathrm{Ca}-\mathrm{SST}$ values for the Holocene corals that are significantly lower than the calculated Sr/Ca-SST values for the same samples, and $\mathrm{Mg} / \mathrm{Ca}$ SST values are also in conflict with coral reef ecology. The unreliability of coral $\mathrm{Mg} / \mathrm{Ca}$ as a thermometer can be interpreted as being due to the presence of a trace amount of microbialites (with $\mathrm{MgO}$ up to $17 \%$, Sr only 100-300 ppm). Preferential loss of Mg during meteoric dissolution of cryptic Mg-calcite-bearing microbialites in the exposed fossil corals (Yu et al., 2005a) will result in reconstructed $\mathrm{Mg} / \mathrm{Ca}$-SSTs being too low.

Using combined $\delta^{18} \mathrm{O}$ and $\mathrm{Sr} / \mathrm{Ca}$ measurements from five Porites corals, mid-late Holocene climate was reconstructed, revealing a general decreasing trend in SST in the SCS from $\sim 6,800$ to 1,500 years ago ( $Y u$ et al., 2005b), despite shorter climatic cycles. Compared with mean $\mathrm{Sr} /$ Ca-SST in the 1990s, 10-year mean $\mathrm{Sr} / \mathrm{Ca}-\mathrm{SST}$ s were $0.9-0.5^{\circ} \mathrm{C}$ higher during 6.8-5.0 kyr BP, dropped to the present level by $\sim 2.5 \mathrm{kyr} B \mathrm{~B}$, and reached a low of $22.6^{\circ} \mathrm{C}\left(2.2^{\circ} \mathrm{C}\right.$ lower $)$ by $\sim 1.5$ kyr BP. Such a decline in SST is accompanied by a similar decrease in the amount of monsoon moisture transported out of SCS, resulting in a general decrease in seawater $\delta^{18} \mathrm{O}$ 


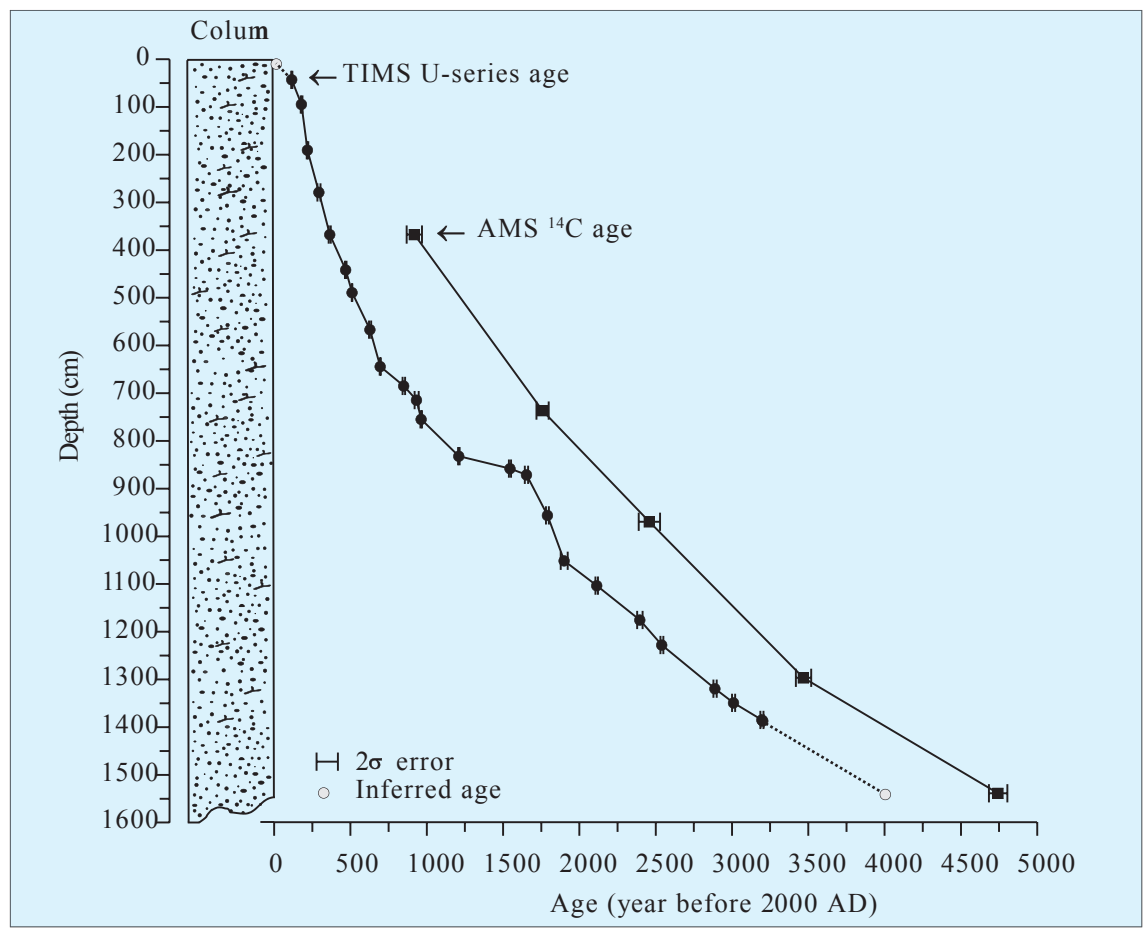

Fig. 1: Lagoon sediment column from Yongshu Reef $\left(9^{\circ} 32^{\prime}-9^{\circ} 42^{\prime} \mathrm{N}, 112^{\circ} 52^{\prime}-113^{\circ} 04^{\prime} \mathrm{E}\right)$, southern South China Sea and TIMS U-series and AMS ${ }^{14} \mathrm{C}$ age distribution. The age offset between TIMS $U$-series and $A M S{ }^{14} \mathrm{C}$ age sequences should be related to radiocarbon reservoir effect.

values, reflected by offsets of mean $\delta^{18} \mathrm{O}$ relative to that in the 1990s. This observation is consistent with general weakening of the East Asian Summer Monsoon since the early Holocene, in response to a continuous decline in solar radiation, which was also found in pollen, lake-level and loess/paleosol records throughout mainland China.

In contrast to the general cooling trend of the monsoon climate in East Asia, SST has increased dramatically in recent times, with that in the 1990 s being $2.2^{\circ} \mathrm{C}$ warmer than $\sim 1,500$ years ago. This might suggest that the increase in the concentration of anthropogenic greenhouse gases has played a dominant role in recent global warming, which has reversed the natural climatic trend in the East Asian monsoon regime. If more corals are analyzed for the last 1,500 years, a clearer picture of environmental response to human activities in the South China Sea can be obtained.

Over 200 samples from different reef areas of the SCS, each covering a 30- to 150-year growth history, were dated for U-series ages with high-precision thermal ionization mass spectrometry (TIMS). The ages of these corals cover the entire last 7,500 years, providing a unique archive for us to reconstruct mid-late Holocene climate history in the SCS using combined high-resolution multi-proxy records. These ages and their elevations also reveal that multiple sea-level highstands of $\sim 2 \mathrm{~m}$ above the present sea-level occurred at 7100 to $6300,5717 \pm 27,5009 \pm 54$, $4156 \pm 23$ to $3675 \pm 23,2795 \pm 14$ to $2509 \pm 10 \mathrm{yr}$, and $1511 \pm 23 \mathrm{yr}$ BP, respectively. This suggests a possible linkage between high-latitude climate fluctuating cycles and lowlatitude coral reef development.

\section{High-frequency Winter Cooling and Coral Cold Bleaching During Mid-Holocene Warm Period}

A detailed ecological, micro-structural and skeletal Sr/Ca study of a 3.42-m-thick Goniopora reef profile from an emerged Holocene reef terrace at the northern SCS reveals that at least nine abrupt massive Goniopora stress and mortality events ("cold-bleaching") occurred in winter during 7.0 7.5 cal ka BP (within the Holocene climatic optimum, Yu et al., 2004a). Whilst calculated Sr/Ca-SST maxima during this period are comparable to those in the 1990s, Sr/Ca-SST minima are significantly lower, probably due to larger seasonality and stronger winter monsoons. Such generally cooler winters, superimposed by further exceptional winter cooling on interannual-to-decadal scales, may have caused stress (cold bleaching) and mortality of the corals about every 50 years. Modern cold bleaching was reported to have occurred on Heron Island in the Great Barrier Reef in 2003.

This study provides the first prehistoric evidence for cold-bleaching of reef corals at higher latitudes and adds new dimension to the understanding of coral bleaching. The results also show that it took about 20-25 years for a bleached Goniopora coral reef to recover, which greatly aids our understanding of the present global warming-induced bleaching phenomenon and the recovery process.

During this period of reef growth, sea level rose by $\sim 3.42 \mathrm{~m}$, present sea-level was reached by $\sim 7.3 \mathrm{ka} B P$ and a sea-level highstand of at least $\sim 1.8 \mathrm{~m}$ occurred at $\sim 7.0 \mathrm{ka}$.

\section{High-precision TIMS U-series and AMS 14C Dating of a 4,000- year-old Coral Reef Lagoon Core from Southern South China Sea}

Worldwide, corals have contributed significantly to the understanding of global climate change, however few corals cover continuous records of several hundred years. The lack of continuous long records for the Holocene has greatly impeded systematic high-resolution climate reconstruction of tropical oceans. Although some deep-sea cores have been archived from tropical oceans, the time resolution is far too low to resolve the annual-to-decadal scale climate changes due to their lower sedimentation rates. Coral reef lagoon profiles, with high sedimentation rates, have great potential for recording long-term high-resolution continuous environmental change but their widespread application has so far been limited by the lack of accurate dates.

Our new research, based on 26 high-precision TIMS U-series dates (for 25 coral branches) and 5 AMS ${ }^{14} \mathrm{C}$ dates (for foraminifera) for a 15.4$\mathrm{m}$-long lagoon core from Yongshu Reef, southern SCS, show that all the dates are in the correct strati- 
graphical sequence, although the smallest sampling interval is only 13 $\mathrm{cm}$, and they reveal a 4,000-year continuous depositional history (Fig. 1). The results indicate that the deposition rate varied in the range of 0.8 and $24.6 \mathrm{~mm} / \mathrm{yr}$, with an average of $3.85 \mathrm{~mm} / \mathrm{yr}$. Two fast deposition periods, one from 103 to $305 \mathrm{AD}$ and the other for the last 1,000 years, are identified. Episodes of elevated depositions within the last 1,000 years correlate well in timing with strong storm events identified from Useries dates of storm-relocated coral blocks in the area (Yu et al., 2004b). Therefore, coral reef lagoon profiles provide great potential for highresolution (4-10 years) and continu- ous climate and environmental reconstruction in the tropical oceans.

Apart from the above outlined research topics, we are also undertaking research on $U$-series dating of recent coral mortality history, sea-level fluctuation on millennialto-century scales, and radiocarbon reservoir age change in the SCS since the mid-Holocene.

\section{REFERENCES}

Zhang, Q.M., Yu, K.F., Shi, Q. and Zhao, M.X., 2005: The Outcome of Global Coral Reef Monitoring and the New Strategy for Global Coral reef Conservation and Management, (in Chinese with English abstract).

Yu, K.F., Zhao, Y.X., Wei, G.J., Cheng, X.R., Chen, T.G., Wang, P.X. and Liu, T.S., 2005a: $\delta^{18} 0$, Sr/Ca and $\mathrm{Mg} / \mathrm{Ca}$ records of Porites lutea corals from Leizhou Peninsula, northern South China Sea and their applicability as paleothermometers, Palaeogeography Palaeoclimatology Palaeoecology, 218: $57-73$.

Yu, K.F., Zhao, J.X., Wei, G.J., Cheng, X.R. and Wang, P.X., 2005b: Mid-late Holocene monsoon climate retrieved from seasonal $\mathrm{Sr} / \mathrm{Ca}$ and $\delta^{18} 0$ records of Porites lutea corals at Leizhou Peninsula, northern coast of the South China Sea, Global and Planetary Change (in press).

Yu, K.F., Zhao, J.X., Liu, T.S., Wei, G.H., Wang, P.X. and Collerson, K.D., 2004a: High-frequency winter cooling and reef coral mortality during the Holocene climatic optimum, Earth and Planetary Science Letters, 224(1-2): 143-155.

Yu, K.F., Zhao, J.X., Collerson, K.D., Shi, Q., Chen, T.G., Wang P.X. and Liu, T.S., 2004b: Storm cycles in the last millennium recorded in Yongshu Reef, southern South China Sea, Palaeogeography Palaeoclimatology Palaeoecology, 210(1): 89-100.

\section{Sorting Chinese Climate Records from the 13th Century BC to 1911 $\mathrm{AD}$ and their Latest Applications}

\section{DE' ER ZhANG}

National Climate Center, Beijing 100081, China; derzhang@cma.gov.cn

A myriad of historical documentary records in China preserves one of the paramount sources of paleoclimate data marked by definite description of place and time of climate events over thousands of years, and is thus of particular importance to chronologically calibrating such proxy data as tree rings, ice cores and sediments, not to mention their strong humanism inference. Chinese researchers began in 1985 to assemble and sort systematically the meteorological records from historical documents, and have recently finished a book entitled "A Compendium of Chinese Meteorological Records of the Last 3000 Years" (Zhang, 2004).

Compiled on a chronological basis, this collection represents a splendid archive of ancient Chinese cultural heritage and scientific contributions, covering various weather/climatic conditions, atmospheric physical phenomena, and other written records related to meteorological conditions over 3,000 years, from the 13th century BC to 1911 AD (Fig. 1).

This compendium is composed of four volumes. Each volume contains the following records: (1) descriptions of weather, climate, and atmospheric physical phenomena, including flood, drought, rain, snow,

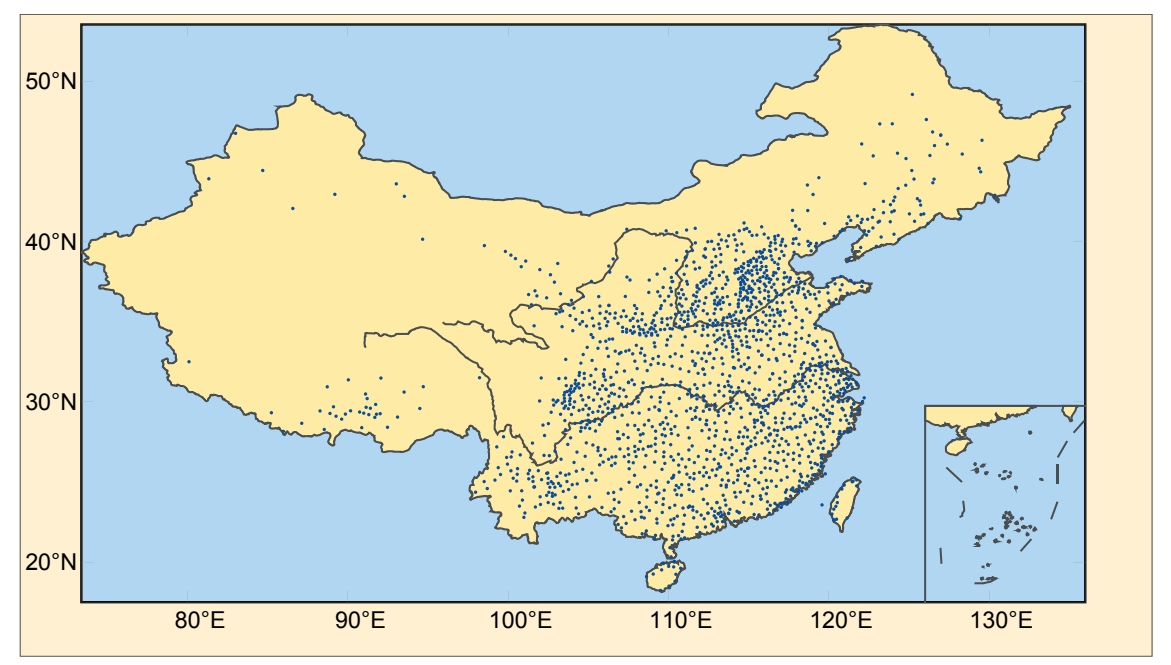

Fig. 1: Distribution of places of the historical climate records in the Compendium.

cold, heat, icing, freezing, frost, hail, wind, dust and haze, storm, thunder and lightning, atmospheric optical phenomena, and the time and location of these phenomena; (2) spatial coverage and degree of damage caused by meteorological disasters and the relief and tax waiver afterwards, and; (3) phonological, crop yield, insect damage, plague and famine records that are related to meteorological conditions. Because of the very large quantity of records starting from the Ming Dynasty, records of the same year in the Ming and Oing Dynasties (1368-1911 AD) are further sorted according to their provincial locality. Modern names for the recorded localities are also given for convenience.

The original data came from 65 libraries and archives in 37 cities of the country, and they were collected according to different categories prepared in advance. We have read through all the books and records for seeking and selecting, with the materials made into various duplications (photocopies, microfilms and hand-written copies). The books and records selected amount to 8,228 , of which 7,835 were chosen, including 7,713 local chronicles, 28 kinds of chronicles and many official docu- 